\title{
The Mandibular Landmarks about the Facial Artery and Vein with Multidetector Computed Tomography Angiography (MDCTA): an Anatomical and Radiological Morphometric Study
}

\author{
Puntos de Referencia de la Mandíbula Relacionados a la Arteria y Vena Facial con Angiografía por \\ Tomografía Computarizada Multidetector (ATCM): un Estudio Morfométrico Anatómico y Radiológico
}

"Aynur Emine Cicekcibasi; *Mehmet Tugrul Yılmaz; *"Demet Kıresi \& *Muzaffer Seker

CICEKCIBASI, A. E.; YILMAZ, M. T.; KIRESI, D. \& SEKER, M. The mandibular landmarks about the facial artery and vein with multidetector computed tomography angiography (MDCTA): an anatomical and radiological morphometric study. Int. J. Morphol., 30(2):504-509, 2012.

SUMMARY: The aim of this study was to investigate the course of the facial vessels according to several mandibular landmarks in living individuals using multidetector computed tomography angiography (MDCTA) to determine these related to sex and side. This study was conducted in the Radiology Department, Meram Faculty of Medicine, Necmettin Erbakan University (Konya, Turkey). In total, sixty faces from 30 specimens ( 15 males and 15 females) with symptoms and signs of vascular disease were evaluated for the facial vessels by MDCTA scan. The facial vessel parameters were measured according to the reference points (mandibular angle, mental protuberance, mental foramen and facial midline). The distance from the point at which the facial artery first appears in the lower margin of the mandible to the mandibular angle for right and left facial artery were observed as $3.53 \pm 0.66 \mathrm{~cm}$ and $3.31 \pm 0.73 \mathrm{~cm}$ in males, respectively. These distances were determined as $2.91 \pm 0.52 \mathrm{~cm}$ and $3.35 \pm 0.48 \mathrm{~cm}$ in females. MDCTA is a new, powerful, safe and noninvasive test to demonstrate the vasculature of the head. Bony structures and neighboring vessel morphology can be evaluated by this technique in cases of trauma with suspected vessel injuries and when considering patient selection for flap surgery.

KEY WORDS: Facial artery; Facial vein; Multidetector computed tomography angiography; Mandibular landmarks; Anatomy.

\section{INTRODUCTION}

The facial vessels may be injured during various maxillofacial surgery and anesthetic dental-plastic procedures in the facial and submandibular regions. Therefore, knowledge of the location of facial vessels according to some mandibular landmarks is necessary in this region.

The facial artery provides the blood supply of the large portion of the anterior face (Ariji et al., 2001; Ariji et al., 1998; Lasjaunias et al., 1979). It enters the face at the lower mandible anterior to the masseter muscle and runs upward and forward tortuously toward the angle of the mouth. Previous studies have shown that there is a racial variation in the origin and the branches patterns of the facial artery (Koh et al., 2003; Nakajima et al., 2002; Niranjan, 1988). Facial vessels are widely used in plastic surgery as the pedicle of some flaps (D'Arpa et al., 2009; Hofer et al., 2005; Joshi et al., 2005; Pribaz et al., 1992; Yamauchi et al., 2010). The flap based on the facial artery could be originated from the proximal or distal portion of the artery. The assessment of facial vasculature is especially important when considering both donor and recipient selection for facial flaps and careful surgical planning is necessary to successful results (Renshaw et al., 2007).

The multidetector computed tomography (MDCT) enables faster scanning time, a wider area of scan coverage, higher resolution of the volume data than single helical computed tomography (CT) and less use of contrast substance. Advancements in MDCT have provided high quality computed tomography angiography (CTA) images by improved CT scanning methods. CTA is a rapidly developing technology

\footnotetext{
* Department of Anatomy, Meram Medical Faculty, Necmettin Erbakan University, Konya, Turkey.

** Department of Radiology, Meram Medical Faculty, Necmettin Erbakan University, Konya, Turkey.
} 
with great potential. Postprocessing techniques for CTA include maximal intensity projection (MIP), multiplanar reconstruction (MPR), and volume rendering (VR) that is done at the three-dimensional (3D) workstation (Forsting, 2005; Wintermark et al., 2003). At present multidetector computed tomography angiography (MDCTA) provides the best spatial resolution for almost all vascular territories. MDCTA has expanded and dramatically improved most applications of CTA and in many cases will become the new gold standard for vascular imaging (Prokop, 2000).

In this study, we aimed to determine the course according to several mandibular landmarks of the facial vessels in living individuals using MDCTA and to evaluate these related to sex and side.

\section{MATERIAL AND METHOD}

Sixty faces from 30 specimens (15 males and 15 females) were evaluated for facial vessels. None of the cases in the study had trauma history or structural abnormality of the craniocervical region. There were no contraindications for intravenously administered iodinated contrast material in all cases. For optimal intraluminal contrast enhancement, the delay time between the start of contrast material administration and the start of scanning was determined for each patient individually by using a bolus-tracking technique. For this purpose, a single slice no enhanced image at the level of the distal common carotid artery was obtained first. On this baseline image, a region of interest with an area of

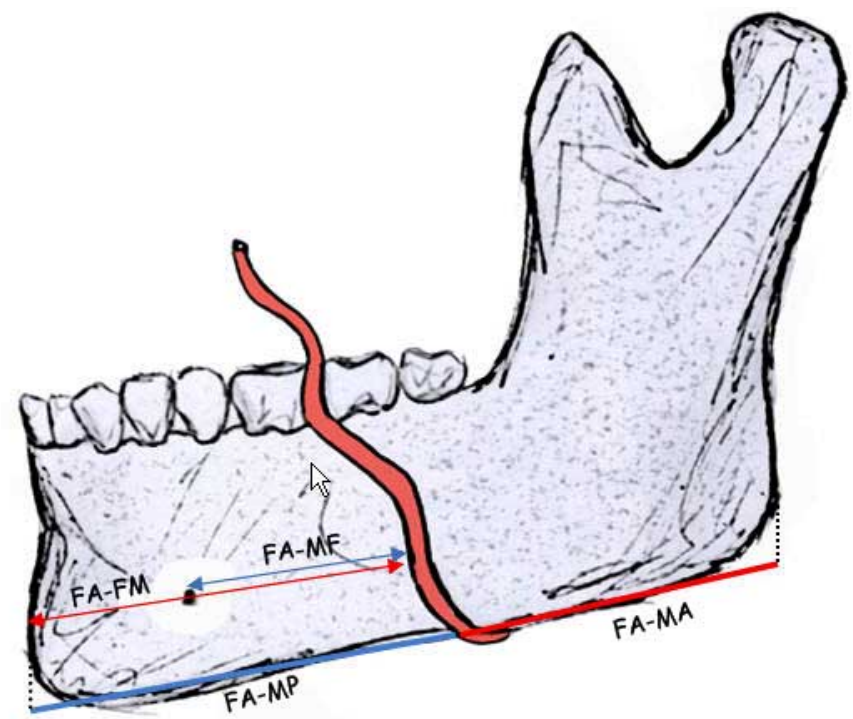

Fig. 1. Schematic diagram of the measurement sites. Facial artery (FA), mandibular angle (MA), mental protuberance (MP), mental foramen $(\mathrm{MF})$, facial midline (FM).
$3-5 \mathrm{~mm}^{2}$ was set in the lumen of the distal common carotid artery. This region of interest served as a reference for the following dynamic measurements of contrast enhancement. A total of $80-100 \mathrm{~mL}$, a low-osmolar iodinated contrast material, was administered through a peripheral vein. When the Hounsfield units (HU) in the preset lumen of the distal common carotid artery rose by 100 , the MDCTA scanning was triggered automatically $3 \mathrm{~s}$ later. Parameters for the CT angiographic acquisition were $0.75 \mathrm{~mm}$ section thickness, pitch of $1.2,100 \mathrm{kV}$, and $160 \mathrm{mAs}, 512$ x 512 matrix, and $20 \mathrm{~cm}$ FOV.

All MDCTA examinations were performed with a 64channel MDCTA scanner (Somatom Sensation 64, Siemens, Germany). The images were obtained in an optimal neutral head position without rotation, flexion or extension in order to provide standardized measurements. Measurements were done with coronal CT slices. The images were retrieved to the Leonardo workstation (Siemens Medical Solutions). All measurements were made by visual estimation of the determined points at an approximate window setting and a level setting. The software (syngommwp VE 30A, syngo VE32B) calculated all measurements and they were recorded in centimeters.

The determined parameters were recorded according to the reference points (mandibular angle, mental protuberance, mental foramen and facial midline) and were as follows:

1. The distance from the point at which the facial artery and vein first appears in the lower margin of the mandible to the mandibular angle (FA - MA; FV - MA).

2. The distance from the point at which the facial artery and vein first appears in the lower margin of the mandible to the

mental protuberance (FA - MP; FV - MP).

3. The distance from the facial artery and facial vein to the mental foramen at the level of the mental foramen (FA $\mathrm{MF} ; \mathrm{FV}-\mathrm{MF})$.

4. The distance from the facial artery and facial vein to the facial midline at the level of the mental foramen (FA-FM; FV - FM) (Figs. 1, 2a-2b, 3a-3b).

All data were entered for use with the Statistical Package for the Social Sciences (Version 13.0; SPSS). Gender comparison was performed by the Mann-Whitney U test. The differences between the right and left measurement values were analyzed statistically by the Wilcoxon signed rank test. Statistical significance was defined as $\mathrm{p}<0.05$. This study conformed to Helsinki Declaration. 

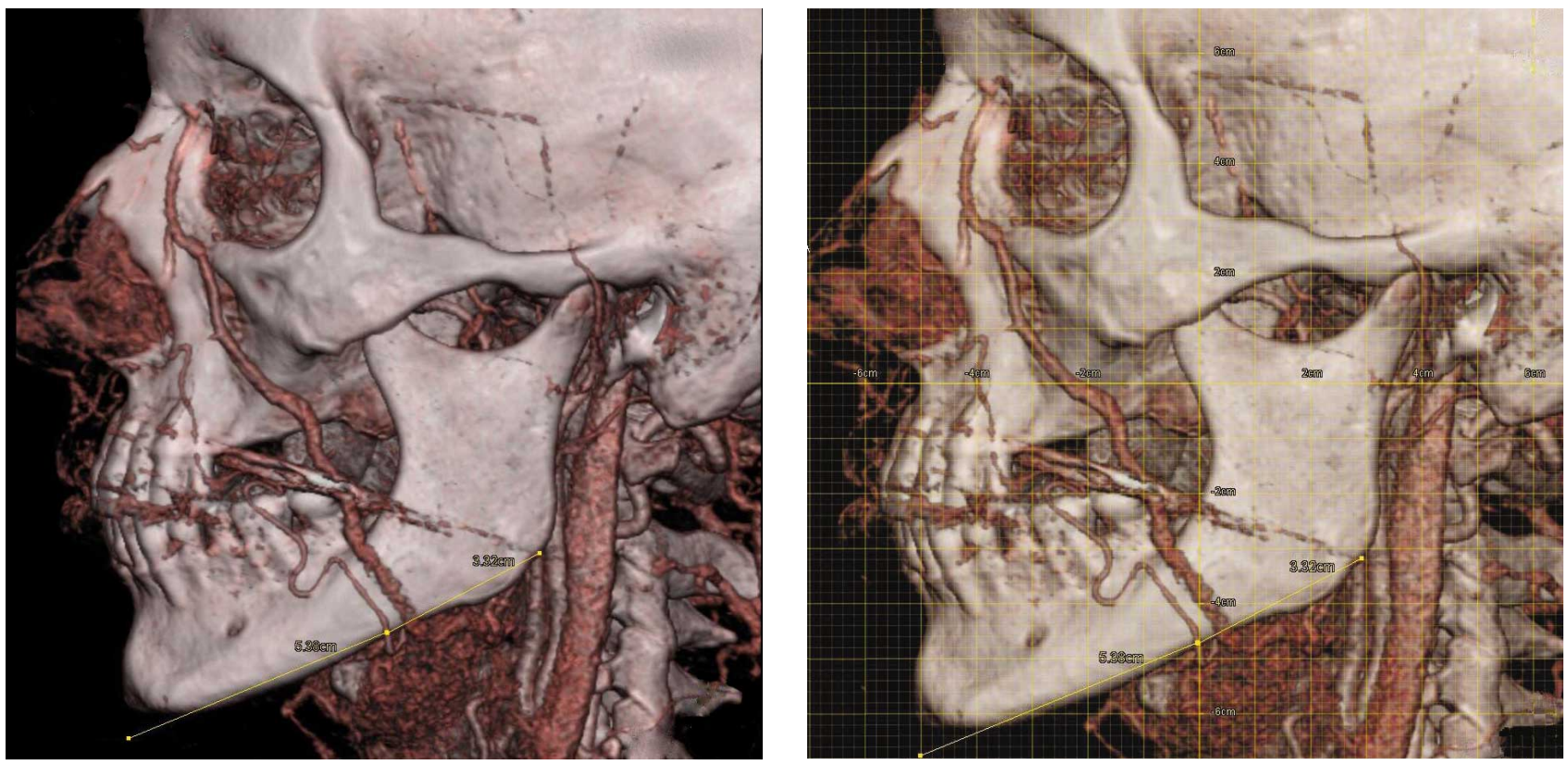

Figs. 2a-2b. The measured parameters for the facial artery (left side) 1. The distance from the point at which the facial artery first appears in the lower margin of the mandible to the mandibular angle 2. The distance from the facial midline (mental protuberence).
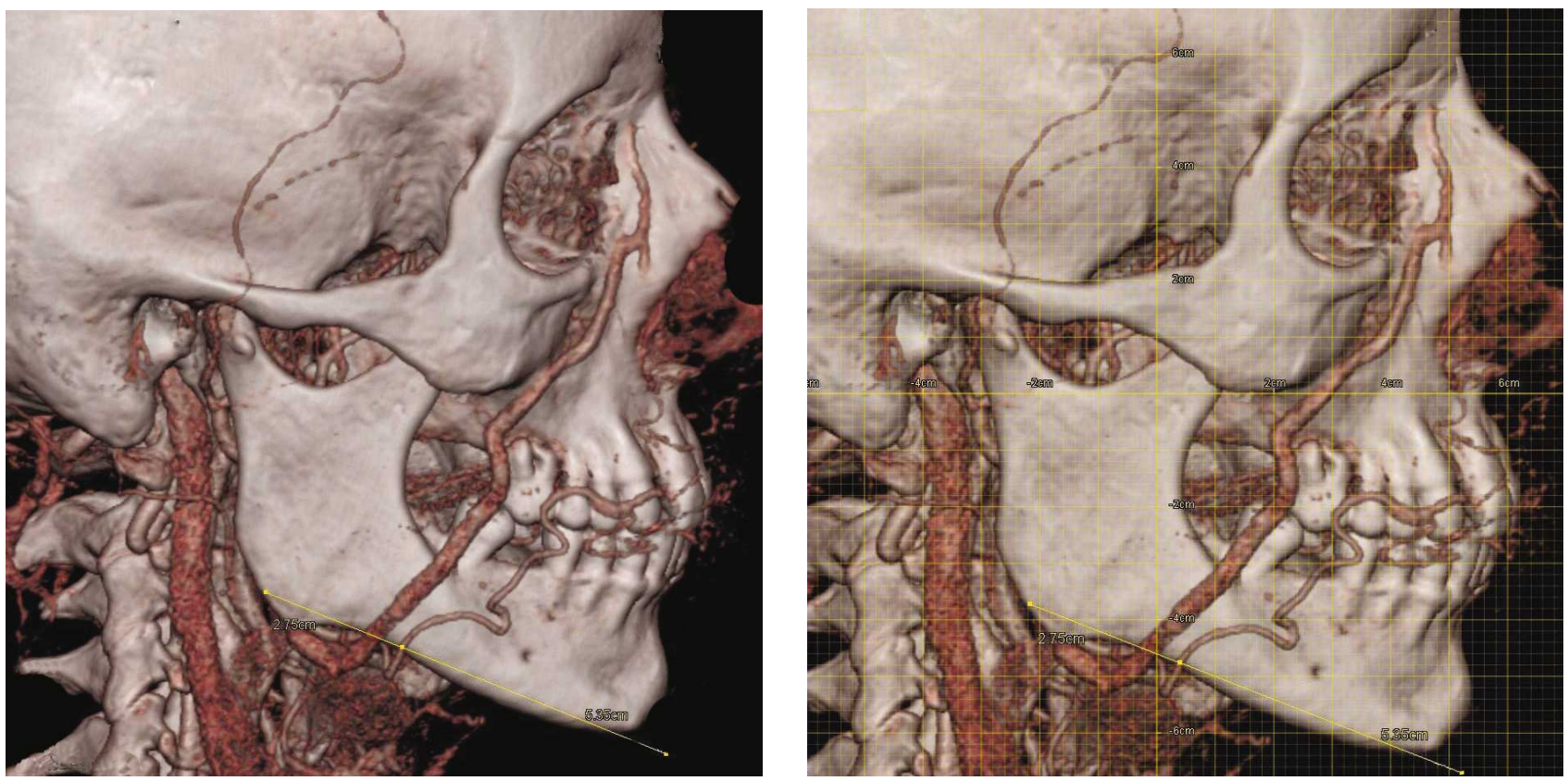

Figs. 3a-3b. The measured parameters for the facial artery (right side) 1 . The distance from the point at which the facial artery first appears in the lower margin of the mandible to the mandibular angle 2 . The distance from the facial midline (mental protuberance).

\section{RESULTS}

In males 1 . The distance from the point at which the facial artery first appears in the lower margin of the mandible to the mandibular angle for right and left facial artery were $3.53 \pm 0.66 \mathrm{~cm}$ (range 2.39 to 5.10 ) and $3.31 \pm 0.73 \mathrm{~cm}$ (range 


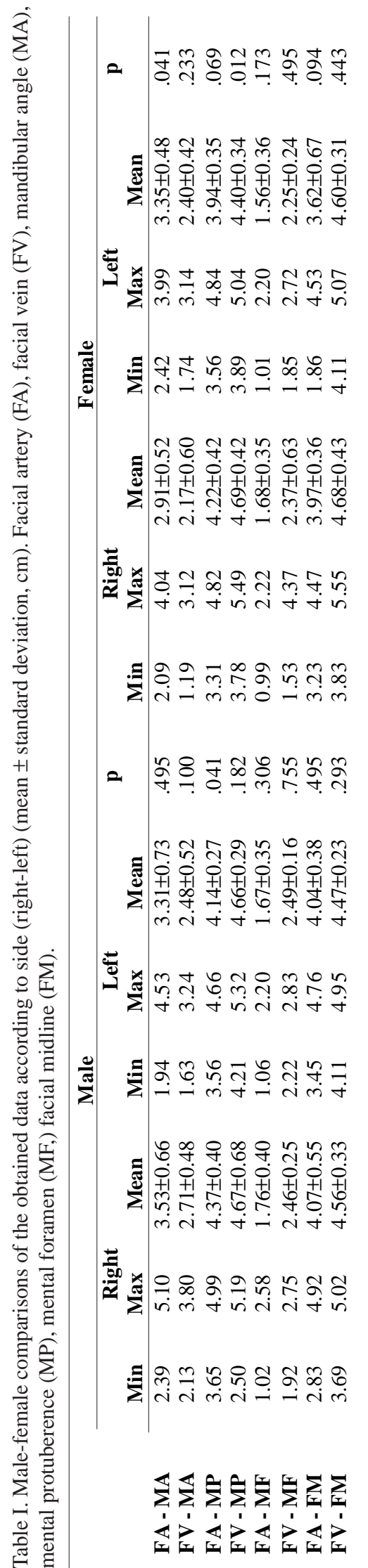

1.94 to 4.53 ), respectively. This distance for right and left facial vein were $2.71 \pm 0.48$ $\mathrm{cm}$ (range 2.13 to 3.80 ) and $2.48 \pm 0.52 \mathrm{~cm}$ (range 1.63 to 3.24 ), respectively.

2. Right and left facial artery were determined to be $4.37 \pm 0.40 \mathrm{~cm}$ (range 3.65 to 4.99 ) and $4.14 \pm 0.27 \mathrm{~cm}$ (range 3.56 to 4.66 ) lateral to the mental protuberance, respectively. This distance for right and left facial vein were $4.67 \pm 0.68 \mathrm{~cm}$ (range 2.50 to 5.19 ) and $4.66 \pm 0.29 \mathrm{~cm}$ (range 4.21 to 5.32 ), respectively.

3. The distance from the facial artery to the mental foramen for right and left facial artery were $1.76 \pm 0.40 \mathrm{~cm}$ (range 1.02 to 2.58 ) and $1.67 \pm 0.35 \mathrm{~cm}$ (range 1.06 to 2.20 ), respectively. This distance for right and left facial vein were $2.46 \pm 0.25$ (range 1.92 to 2.75 ) and $2.49 \pm 0.16 \mathrm{~cm}$ (range 2.22 to 2.83 ), respectively.

4. Right and left facial artery were determined to be $4.07 \pm 0.55 \mathrm{~cm}$ (range 2.83 to 4.92 ) and $4.04 \pm 0.38 \mathrm{~cm}$ (range 3.45 to 4.76 ) lateral to the facial midline, respectively. This distance for right and left facial vein were $4.56 \pm 0.33 \mathrm{~cm}$ (range 3.69 to 5.02 ) and $4.47 \pm 0.23 \mathrm{~cm}$ (range 4.11 to 4.95 ), respectively (Table I).

In females. 1. The distance from the point at which the facial artery first appears in the lower margin of the mandible to the mandibular angle for right and left facial artery were $2.91 \pm 0.52 \mathrm{~cm}$ (range 2.09 to 4.04 ) and $3.35 \pm 0.48 \mathrm{~cm}$ (range 2.42 to 3.99 ), respectively. This distance for right and left facial vein were $2.17 \pm 0.60$ $\mathrm{cm}$ (range 1.19 to 3.12 ) and $2.40 \pm 0.42 \mathrm{~cm}$ (range 1.74 to 3.14 ), respectively.

2. Right and left facial artery were determined to be $4.22 \pm 0.42 \mathrm{~cm}$ (range 3.31 to 4.82 ) and $3.94 \pm 0.35 \mathrm{~cm}$ (range 3.56 to 4.84 ) lateral to the mental protuberance, respectively. This distance for right and left facial vein were $4.69 \pm 0.42 \mathrm{~cm}$ (range 3.78 to 5.49 ) and $4.40 \pm 0.34 \mathrm{~cm}$ (range 3.89 to 5.04 ), respectively.

3. The distance from the facial artery to the mental foramen for right and left facial artery were $1.68 \pm 0.35 \mathrm{~cm}$ (range 0.99 to 2.22 ) and $1.56 \pm 0.36 \mathrm{~cm}$ (range 1.01 to 2.20 ) , respectively. This distance for right and left facial vein were $2.37 \pm 0.63 \mathrm{~cm}$ (range 1.53 to 4.37 ) and $2.25 \pm 0.24 \mathrm{~cm}$ (range 1.85 to 2.72 ), respectively.

4. Right and left facial artery were determined to be $3.97 \pm 0.36 \mathrm{~cm}$ (range 3.23 to 4.47 ) and $3.62 \pm 0.67 \mathrm{~cm}$ (range 1.86 to 4.53 ) lateral to the facial midline, respectively. This distance for right and left facial vein were $4.68 \pm 0.43 \mathrm{~cm}$ (range 3.83 to 5.55 ) and $4.60 \pm 0.31 \mathrm{~cm}$ (range 4.11 to 5.07 ), respectively (Table I).

The statistically significant differences were not found between right and

Table II. $\mathrm{P}$ values of the obtained data between gender $(\mathrm{P}<0.05)$

\begin{tabular}{|c|c|c|}
\hline & Right & Left \\
\hline & \multicolumn{2}{|c|}{ p value } \\
\hline FA - MA & .009 & .744 \\
\hline FV - MA & .021 & .806 \\
\hline FA - MP & .367 & .056 \\
\hline FV - MP & .389 & .045 \\
\hline FA - MF & .512 & .412 \\
\hline FV - MF & .126 & .007 \\
\hline FA - FM & .512 & .137 \\
\hline FV - FM & .436 & .325 \\
\hline
\end{tabular}
left sides except FA - MP in males, while were not found except for FA - MA, FV MP in females (Table I). In addition, no significant differences were observed between male and female except right FA - MA, right FV - MA, left FV - MP, left FV - MF (Table II).

The anatomical data were usually observed larger in males than females and on the right face side than the left side. 


\section{DISCUSSION}

The facio-maxillary region has a vital importance and facial artery has been suggested as the basic vascular pedicle in facial flaps (D'Arpa et al.; Hofer et al.; Joshi et al.; Pribaz et al.; Yamauchi et al.). The evaluation of the facial vessels of this anatomic region with MDCTA prior to orbital, facial, dental surgery may prevent intraoperatively vascular injuries (Marco de Lucas et al., 2008). Preoperative evaluation is especially important in flap surgery and mandibular fractures.

The facial artery arises from the external carotid artery. The artery runs tortuously across the anterior face; the vein, more directly (Renshaw et al.). The facial artery and vein were located together at the lower margin of the mandible (Zhao et al., 2000). The racial, gender and side differences may be at the mandibular crossing point of the facial vessels. In a cadaver study which the topography and the course of the facial artery were investigated the average distance from the mandibular angle to the point where the facial artery appears at the lower margin of the mandible was revealed as $27.2 \pm 5.6 \mathrm{~mm}$ in males and $26.8 \pm 4.8 \mathrm{~mm}$ in females. It was reported that the courses of the facial arteries showed no significant differences based on either laterality or gender (Koh et al.). Zhao et al. measured the distances from each other of the facial artery and vein at the different levels. In our study, the distances were measured from the facial midline and the certain anatomical landmarks to facial artery and vein. It was thought that the distances from each other of the facial vessels were not reliable because of especially the tortuously course of the facial artery. The results were found larger in the present study than Koh et al. results probably due to the diversity of subjects.

The diameter of the facial vessels were measured at the lower margin of the mandible in an anatomic study that was done using color Doppler ultrasonography in 12 adults. It was determined that the diameter of the facial artery ranged from 1.7 to $3.6 \mathrm{~mm}$ (mean, $2.6 \mathrm{~mm}$ ) and the diameter of the facial vein ranged from 1.8 to $3.9 \mathrm{~mm}$ (mean, $2.8 \mathrm{~mm}$ ) (Zhao et al.). At the mandibular crossing point, the flow diameter of the facial artery ranged from 1.1 to $3.7 \mathrm{~mm}$ (mean $\pm \mathrm{SD}, 2.6$ $\mathrm{mm} \pm 0.45)$; the facial vein diameter ranged from 1.8 to 5.8 $\mathrm{mm}$ (mean $\pm \mathrm{SD}, 3.1 \mathrm{~mm} \pm 0.61$ ) in the other study that a total of 200 facial vessels were examined (Renshaw et al.).

Several researchers described the course of the marginal mandibular branch of the facial nerve in relationship to the lower edge of the mandible (Basar et al., 1997; Kim et al., 2009; Potgieter et al., 2005). Facial vessels show the close contact with the marginal mandibular branch at the mandibular crossing point. Both structures have risk during surgical procedures in the submandibular region. This anatomic relationship between facial vessels, marginal mandibular branch and adjacent structures are needed to pay attention on the region for safely identification and previously preservation during surgical approaches.

According to our knowledge, there is not an anatomic study that the morphometric diameters of the facial vessels were measured according to mandibular landmarks except Koh et al. cadaver study (Koh et al.) and Renshaw et al. color Doppler ultrasound study. A few measurements were performed in these studies. Therefore, the present study was planned to obtain the reliable data and to provide more parameters.

MDCTA is a safe and noninvasive test and provides a excellent radiological method of preoperative vascular evaluation to establish the feasibility of raising flaps. In addition, the bone structures and facial foramina that very important nerves originated from their location can be evaluated with this method. We conclude that the measurements in the lower margin of the mandible can serve as an important landmark to avoid injury to the facial vessels.

CICEKCIBASI, A. E.; YILMAZ, M. T.; KIRESI, D. \& SEKER, M. Puntos de referencia de la mandíbula relacionados a la arteria y vena facial con angiografía por tomografía computarizada multidetector (ATCM): un estudio morfométrico anatómico y radiológico. Int. J. Morphol., 30(2):504-509, 2012.

RESUMEN: El objetivo de este estudio fue investigar el curso de los vasos faciales de acuerdo con varios puntos de referencias mandibulares en sujetos vivos mediante angiografía por tomografía computarizada multidetector (ATCM) para determinar si éstos están relacionados con el sexo y el lado. El estudio se llevó a cabo en el Departamento de Radiología, Facultad de Medicina de Meram en Necmettin Erbakan (Konya, Turkey). En total, sesenta caras de 30 sujetos (15 hombres y 15 mujeres), que presentaban síntomas y signos de la enfermedad vascular fueron evaluados para explorar los vasos faciales por ATCM. Los parámetros sobre los vasos faciales se midieron en relación a puntos de referencia (ángulo de la mandíbula, proceso mental, foramen mental y línea mediana facial). La distancia desde el punto en el que la arteria facial aparece por primera vez en el margen inferior de la mandíbula hasta el ángulo mandibular de la arteria facial derecha y izquierda fueron $3,53 \pm 0,66 \mathrm{~cm}$ y $3,31 \pm 0,73 \mathrm{~cm}$ en hombres, respectivamente. En mujeres fueron $2,91 \pm 0,52 \mathrm{~cm}$ y $3,35 \pm 0,48 \mathrm{~cm}$. La ATCM es un examen nuevo, poderoso, seguro y no invasivo para demostrar la vascularización de la cabeza. Las estructuras óseas y la morfología de los vasos vecinos pueden ser evaluados por esta técnica en casos de trauma con sospecha de lesiones de los vasos y se puede considerar de selección en pacientes para realizar cirugías de colgajo.

PALABRAS CLAVE: Arteria facial; Vena facial; Angiografía por tomografía computarizada multidetector; Puntos de referencia mandibulares; Anatomía. 


\section{REFERENCES}

Ariji, Y.; Kimura, Y.; Gotoh, M.; Sakuma, S.; Zhao, Y. P. \& Ariji, E. Blood flow in and around the masseter muscle: normal and pathologic features demonstrated by color Doppler sonography. Oral Surg. Oral Med. Oral Pathol. Oral Radiol. Endod., 91(4):472-82, 2001.

Ariji, Y.; Yuasa, H. \& Ariji, E. High-frequency color Doppler sonography of the submandibular gland: relationship between salivary secretion and blood flow. Oral Surg. Oral Med. Oral Pathol. Oral Radiol. Endod., 86(4):476-81, 1998.

Basar, R.; Sargon, M. F.; Tekdemir, I. \& Elhan, A. The marginal mandibular branch of the facial nerve. Surg. Radiol. Anat., 19(5):311-4, 1997.

D'Arpa, S.; Cordova, A.; Pirrello, R. \& Moschella, F. Free style facial artery perforator flap for one stage reconstruction of the nasal ala. J. Plast. Reconstr. Aesthet. Surg., 62(1):36-42, 2009.

Forsting, M. CTA of the ICA bifurcation and intracranial vessels. Eur. Radiol., 15(Suppl. 4):D25-7, 2005.

Hofer, S. O.; Posch, N. A. \& Smit, X. The facial artery perforator flap for reconstruction of perioral defects. Plast. Reconstr. Surg., 115(4):996-1003, 2005.

Joshi, A.; Rajendraprasad, J. S. \& Shetty, K. Reconstruction of intraoral defects using facial artery musculomucosal flap. $\mathrm{Br}$. J. Plast. Surg., 58(8):1061-6, 2005.

Kim, D. I.; Nam, S. H.; Nam, Y. S.; Lee, K. S.; Chung, R. H. \& Han, S. H. The marginal mandibular branch of the facial nerve in Koreans. Clin. Anat., 22(2):207-14, 2009.

Koh, K. S.; Kim, H. J.; Oh, C. S. \& Chung, I. H. Branching patterns and symmetry of the course of the facial artery in Koreans. Int. J. Oral. Maxillofac. Surg., 32(4):414-8, 2003.

Lasjaunias, P.; Berenstein, A. \& Doyon, D. Normal functional anatomy of the facial artery. Radiology, 133(3 Pt. 1):631-8, 1979.

Marco de Lucas, E.; Gutiérrez, A.; González Mandly, A.; GarcíaPire, F.; Marco de Lucas, M. T.; Parra, J. A. \& Sáiz-Bustillo, R. Life-threatening pseudoaneurysm of the facial artery after dental extraction: successful treatment with emergent endovascular embolization. Oral Surg. Oral Med. Oral Pathol. Oral Radiol. Endod., 106(1):129-32, 2008.

Nakajima, H.; Imanishi, N. \& Aiso, S. Facial artery in the upper lip and nose: anatomy and a clinical application. Plast. Reconstr. Surg., 109(3):855-86, 2002, 2002.

Niranjan, N. S. An anatomical study of the facial artery. Ann. Plast. Surg., 21(1):14-22, 1988.
Potgieter, W.; Meiring, J. H.; Boon, J. M.; Pretorius, E.; Pretorius, J. P. \& Becker, P. J. Mandibular landmarks as an aid in minimizing injury to the marginal mandibular branch: A metric and geometric anatomical study. Clin. Anat., 18(3):171-8, 2005.

Pribaz, J.; Stephens, W.; Crespo, L. \& Gifford, G. A new intraoral flap: facial artery musculomucosal (FAMM) flap. Plast. Reconstr. Surg., 90(3):421-9, 1992.

Prokop, M. Multislice CT angiography. Eur. J. Radiol., 36(2):8696, 2000.

Renshaw, A.; Whitwell, K. A.; Berger, L. \& Butler, P. E. The use of color Doppler ultrasound in the assessment of vessels for facial transplantation. Ann. Plast. Surg., 59(1):82-6, 2007.

Wintermark, M.; Uske, A.; Chalaron, M.; Regli, L.; Maeder, P.; Meuli, R.; Schnyder, P. \& Binaghi, S. Multislice computerized tomography angiography in the evaluation of intracranial aneurysms: a comparison with intraarterial digital subtraction angiography. J. Neurosurg., 98(4):828-36, 2003.

Yamauchi, M.; Yotsuyanagi, T.; Ezoe, K.; Saito, T.; Ikeda, K. \& Arai, K. Reverse facial artery flap from the submental region. J. Plast. Reconstr. Aesthet. Surg., 63(4):583-8, 2010.

Zhao, Z.; Li, S.; Xu, J.; Li, Y.; Huang, W.; Yang, M.; Mu, L.; Liu, Y.; Zhai, H.; Jin, J.; Li, J.; Li, J. \& Fu, X. Color Doppler flow imaging of the facial artery and vein. Plast. Reconstr. Surg., 106(6):1249-53, 2000.

\section{Correspondence to:}

Aynur Emine Cicekcibasi, MD

Department of Anatomy

Meram Medical Faculty,

Selcuk University

42080 Meram

Konya

TURKEY

Tel: +903322237246

Fax: +903323236181

Email: aynurcicekcibasi@yahoo.com.tr

Received: 18-09-2011

Accepted: 27-02-2012 